\title{
DETERMINING THE ILLYRIAN ORIGIN FOREST COMMUNITIES OF BEECH FORESTS KARAWANKE - CARINTHIAN ALPS (AUSTRIA)
}

Utvrđivanje ilirske pripadnosti šuma zajednice bukovih šuma Karavanki - Koruške Alpe (Austrija)

\begin{abstract}
Sead Vojniković ${ }^{1}$
\section{Abstract}

The position of the Illyrian vegetation provinces in the Western Balkans was established a long time ago (e.g.: BECK 1901, ADAMOVIĆ 1907...) Illyrian space is linked to: Montenegro, Bosnia and Herzegovina, Croatia and Slovenia. Karawanke An alpine mountain represents the border between Austria and Slovenia but also represents a border area of the Illyrian provinces. Determining phytogeographical affiliation forest communities of beech becomes very important from the aspect of protection under Natura 2000. According to the requirements Nautra 2000 Illyrian beech forests (91K0 - alliance: Aremonio - Fagion), are summaries of interest for protection in Austria. Therefore, it is important to determine vegetational - floristic characteristics of beech forests on Karawankas, from which one could conclude their phytogeographical affiliation. The research in beech forest, (forestry office Hollenburg) have showed the following beech community Anemone trifoliae Fagetum laricetosum TREGUBOV 1957 (syn.: Larici - Fagetum ROBIČ 1971 /n.nudum./ and syn .: Fagetum subalpinum var. geogr. Larix decidua MARINČEK, POLDINI, ZUPANČIČ 1986); Anemone trifoliae - Fagetum typicum TREGUBOV 1957 var. Carex alba MARINČEK, POLDINI, ZUPANČIČ 1986; Salvio Glutinosae Fagetum ZUKRIGI, 1988. Based on floristic characteristics, their structure, syndinamics, it can be concluded that the first two beech communities cannot be classified as the Illyrian beech forests, while community Salvio glutinosae - Fagetum shows similarity with the Illyrian beech forests fresh Aremonio - Fagion (Natura 2000 at $91 \mathrm{~K} 0)$.
\end{abstract}

Key words: Illyrian Provinces, Beech forests, Karawanke, Carinthia, Austria.

\section{INTRODUCTION - Uvod}

The first analysis of Illyrian vegetation was provided by $B$. von MANNAGETTA in year 1901. The following work which defines Illyrian area is done by ADAMOVIĆ L. in year 1907. According to ADAMOVIĆ, 1907 Illyrian zone more or less follows area of central Dinaric Alps. He divided Illyrian zone contains the

\footnotetext{
${ }^{1}$ Faculty of Forestry, University of Sarajevo, Zagrebačka 20, 71000 Sarajevo, BiH
} 

alps (Austria)

following subzones: Bosnian subzone, Herzegovinian-Montenegro subzone, Serbian subzone.

Mentioned researches are important for understanding start position of initial researchers of Balkan flora and vegetation that, actually, Illyrian flora-geographic province covers Dinaric Alps mountain system. This area in fact covers - parts of Slovenia, Croatia, Bosnia and Herzegovina, Serbia, and Montenegro. FUKAREK (1978) mentions central, so called, "corr" zone of Illyrian province that covers space between rivers: Kupa, Korana, Una, Sana and Vrbas (Slovenia, Croatia and Bosnia). However, besides central zone FUKAREK, similar to ADAMOVIĆ describes wider Illyrian space as complex area that can be divided into: Northern (Slovenia-Croatia) Central (Bosnian) Southern (Herzegovina-Montenegro). A similar start position later has MAYER (1985) who provides a map of Balkan Peninsula (with distribution area of Illyrian province covering mentioned countries.

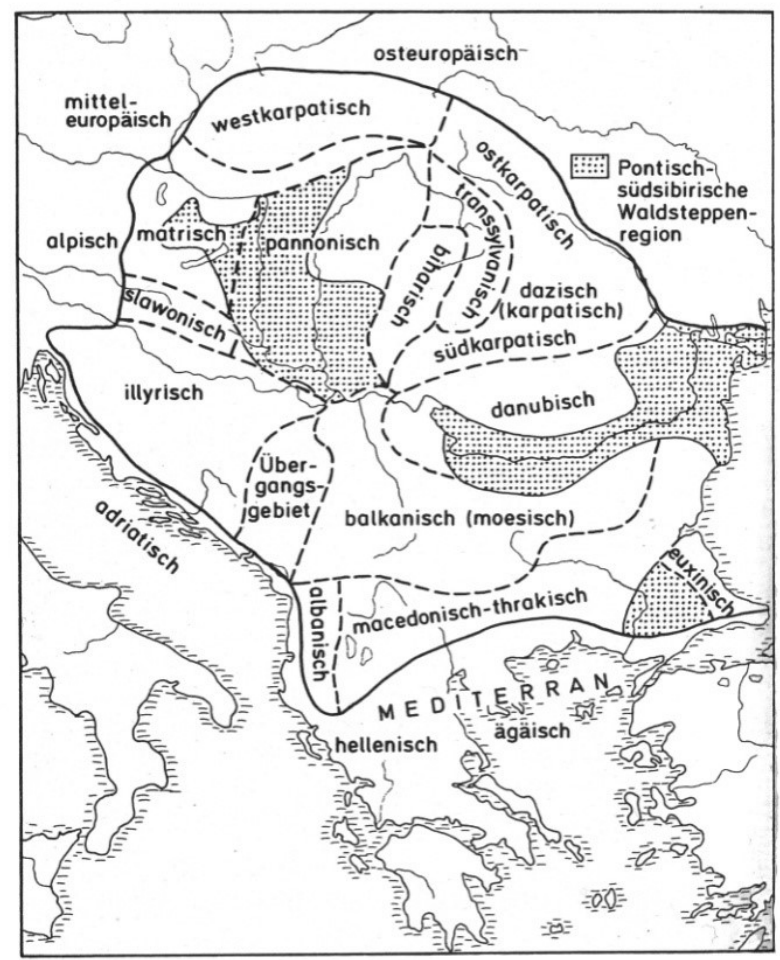

Map 1 - Position of Illyrian province in Balkans (Mayer, 1986) Karta 1. - Položaj ilirske provincije na Balkanu (Mayer, 1986)

In mentioned global - overview map is visible that "classic Illyrian area" does not include area covered by Alps mountain ridge. This area, called Alpine, is completely extracted from Illyrian area. 
If we analyze detailed map of western area of Illyrian province provided by WRABER (1960) for Slovenia and FUKAREK (1980) for ex-Yugoslavia it is visible that according to their understanding further western boundary of Illyrian province ends in Slovenia and does not enter Austria with any of its parts. Analyzing WRABER map from 1960, FUKAREK in 1978 states that, at that time called Fagion illyricum, and now called Aremonio-Fagion (i.e. Illyrian beech forests) includes: Dinaric, preDinaric, pre-Alpine and partially pre-Pannonian sector in Slovenia. Alpine sector is located along Slovenian - Austrian border and further wider in Austria (according to MAYER 1985), and is separated from Illyrian province and Illyrian beech forests.

In classic book that analyses vegetation of southeast Europe „Vegetation Südosteuropas " (HORVAT, GLAVAČ, ELLENBERG, 1974) in details is described boundary of Illyrian province, mentioning by name locations up to which Illyrian province spreads, quote: „Die breite Übergangszone verläuft vom Tolmin- Becken im Soča-Tal (Isonzo) über die Berge um Cerkno, Idrija und Škofja Loka, in das SavaBecken zwischen Kranj und Ljubljana, zieht sich weiter das Sava-Tal hinunter gegen Zidani most (Kum, Veliko Kozje) und über das untere Savinja - Tal in die Talbene des Dravinja-Flusses (Konjiška gora, Boč) und das Tal des Sotla-Flusses (Macelj)“.

Mentioned authors individually for themselves conclude that Illyrian province is located in: Montenegro, Bosnia and Herzegovina, Croatia, and that the western border of Illyrian province ends in Slovenia the furthest in pre-alpine area not entering the Alps (Alpine area). Based on this in wider scale we can conclude that Illyrian province does not enter Austria with either of its part.

However, mentioned border should not be understood „sensu stricto“, i.e. we should understand that this border is diffused. Individual Illyrian species, due to its wide ecological valence, can enter even into Alpine sector, but moving away from the border of Illyrian province they are slowly disappearing. Stated means that only and exclusively on smaller areas within Alpine sector fragments of Illyrian beech forests that are conditioned by orographic - edaphic - micro - climate factors can appear. Therefore, WILLNER et GRABHERR (2007) mention more forest communities of Illyrian beech forests in Austria, for example: Ostryo-Fagetum, Hacquetio-Fagetum, Lamio orvalae-Fagetum... Similar is stated in the Interpretation manual of EU Habitats (2013) that Illyrian beech forests can appear besides Dinaric Alps also in southeast Alps, southeast Carpathians and in mid-Pannonian mountains. It should be emphasized that mentioned areas can only be on limited smaller areas considering that this vegetation in Alpine sector represents extra-zonal vegetation.

\section{RESEARCH AREA AND METHODOLOGY-Područje istraživanja $i$ metodologija}

Area of Forstverwaltung Hollenburg is located on the wider area of AlpsKarawanks in county Klagenfurt between river Drava and border with Republic of Slovenia. The highest point of the area is located on the altitude of 2,237 m (Hochstuhl), and the lowest in the area Unter Waidisch on $532 \mathrm{~m}$. Karawanks spread, 

alps (Austria)

more or less, in direction of east-west. In the area, the most dominant geological base is limestone - dolomite geological base. Soils are series of limestone soils: calcomelanosols, calcaric cambisols, luvisols, and rendzine and colluvium soils. Climate parameters for climate station in Ferlach $(457 \mathrm{~m}$ altitude) show the following parameters: average annual temperature $8.2^{\circ} \mathrm{C}$; average annual precipitation amounts to $1,049 \mathrm{~mm}$, and climate per Köppen scale is marked with $\mathrm{Dfb}$ (wet boreal climate).

Area of Forstverwaltung Hollenburg is divided into more districts: Bärental/Matschachergupf, Bärental, Sinachergupf, Tomaschwald, Zellwinkel, Waidisch/Outschar, Waidisch/Herperschnig, Zell Pfarre, and Gotschuchen.

Narrow locations of research were predetermined in the office based on knowledge of distribution of beech forests within the area. In the field we placed temporary phytocenological experimental plots. On experimental plots we gathered phytocenological records with standard BRAUN-BLANQUET method (1964). Size of the plots are $20 \times 20 \mathrm{~m}\left(400 \mathrm{~m}^{2}\right.$ ), orientation is N-S-E-W. Maps 1 and 2 (in Annex no. 1) shows locations of data gathering, i.e. number of experimental plots and corresponding districts. Plots were placed in as typical habitat and vegetation conditions of appropriate community avoiding vegetation transitions, successions or degradations of the habitat or different anthropogenic impacts.

Table 1. -District title and corresponding number of experimental plot

Tabela 1. - Naziv revira i broj eksperimentalne plohe

\begin{tabular}{|l|l|}
\hline \multicolumn{1}{|c|}{ District title } & Number of experimental plot \\
\hline Bärental/Matschachergupf & 15,16 \\
\hline Bärental & 13,14 \\
\hline Sinachergupf & 2,3 \\
\hline Tomaschwald & 4,5 \\
\hline Zellwinkel & $17,18,19$ \\
\hline Waidisch/Outschar & 1,12 \\
\hline Waidisch/Herperschnig & 8,9 \\
\hline Zell Pfarre & 11,12 \\
\hline Gotschuchen & 6,7 \\
\hline
\end{tabular}

Determination of species was done based on: THOMMEN (1973); LAUBER, K., WAGNER, G., (2001); BLAMEY, M. et GREY-WILSON C., (2008). All data were stored in phytocenological data base Turboveg 2.38 (HENNEKENS et SCHAMINEE 2001), and were processed and analyzed in database Juice 7.0. (TICHY, 2002) as well as in CANOCO (BRAAK, C.J.F. et SMILAUER, P. 2002). For analysis of geofloristic spectrum we used OBERDORFER (1994).

Annex no. 2 shows all ecological data (orographic, structural and pedologicalgeological) related to each individual location. 


\section{RESEARCH RESULTS - Rezultati istraživanja}

\section{Phytocenological analysis - Fitocenološka analiza}

Below there are presenting synthetic phytocenologicaltable covering all nineteen plots that were classified per similarity through the use of Juice software.

Table 2. - Synthetic table of all plots

Tabela 2. - Sintetska ploha svih ploha

(Legend: numbers above the table mark the no. of the plot, numbers in brackets mark the floor where species are appearing: 1 -first layer of trees; 3 - second layer of trees, 5 - bush layer, 6 ground layer floor)

(Legenda: brojevi iznad tabele označavaju br. plohe, brojevi u zagadi označavaju sprat javljanja vrste: 1 -prvi sprat drveća; 3 - drugi sprat drveća, 5 - sprat grmlja, 6 - sprat prizemne flore)

Number of relevés: 19

Fagus sylvatica
Fagus sylvatica
Anemone trifolia
Helleborus niger
Picea abies
Picea abies
Festuca altissima
Cyclamen purpurascens
Larix decidua
Hieracium murorum
Euphorbia amygdaloides
Prenanthes purpurea
Mycelis muralis
Cardamine trifolia
Carex digitata
Daphne mezereum
Fagus sylvatica
Mercurialis perennis
Cardamine enneaphyllos
Picea abies
Vaccinium myrtillus
Lamium galeobdolon
Senecio germanicus
Oxalis acetosella
Acer pseudoplatanus
Abies alba
Abies alba
Sorbus aucuparia
Viola reichenbachiana
Saxifraga rotundifolia

[1]
1011111101100000100 3790814567634259218 4451435345355455233 $1122112+22242132+11$ $2 r 1+.+++.+11+211+\ldots$ ......+r+rr1121212. .3 .3 .2 .33112 .3 .123 $.1 .2 \ldots 1.11111 .12 .11$ $+.+r .+. r r \ldots . . r 2+1 .++$ ..rr+t...rt.r.r+t+1 $111+3413122 \ldots \ldots \ldots$ ..t.r.r..r.trr.r+t rrr.r.....t.trrr. r.1r..t+.r...tr+..r tr...rtr.t.tr......

$+r r++r 2 . r r \ldots . . .$. $.1+\ldots+\ldots \ldots+.1 \ldots+31$ ..r..r...r.rerrr $.2 .1 .+\ldots 1 \ldots 1++.+\ldots$ $r 2 . r \ldots r \ldots r 1+\ldots . r$ r+.rerr.r....... $\ldots+1 \ldots 1 \ldots+.++.1$. $+r 3 r \ldots 3 \ldots .+$....

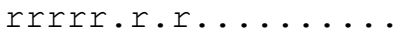
1.rr.rr.r...... $+. r .+r+. r+\ldots \ldots \ldots$. ..r..r...r...r.tr $32 \ldots 1 \ldots 2 \ldots 2.4 \ldots \ldots$ $++\ldots+\ldots 1 \ldots+.1 \ldots \ldots$ $. r \ldots r . r \ldots \ldots 1 \ldots r$ $r . r \ldots . . . . . r r$. ..r.t.r....2... 

alps (Austria)

Picea abies
Dryopteris filix-mas
Neottia nidus-avis
Veronica urticifolia
Actaea spicata
Larix decidua
Salvia glutinosa
Cephalanthera rubra
Fraxinus excelsior
Festuca heterophylla
Brachypodium sylvaticum
Fagus sylvatica
Pinus sylvestris
Sorbus aria
Dryopteris species
Larix decidua
Eupatorium cannabinum
Polygonatum verticillatum
Athyrium filix-femina
Sorbus aria
Abies alba
Polystichum lonchitis
Melampyrum sylvaticum
Aposeris foetida
Adenostyles alpina
Aremonia agrimonoides
Gymocarpium dryopteris
Fragaria vesca
Epilobium montanum
Rubus idaeus
Anemone nemorosa
Luzula sylvatica
Asplenium trichomanes
Hypericum montanum
Otherses

\section{Other species:}

Carex flacca [6] 1: 1; Sorbus aria [5] 1: +; Doronicum columnae [6] 2: r; Polygonatum multiflorum [3] 3: r; Lamium orvala [6] 3: r; Festuca heterophylla [3] 3: r; Actaea spicata [3] 3: r; Abies alba [4] 4: +; Carex alba [6] 4: r; Thalictrum aquilegifolium [6] 7: r; Veratrum album [6] 7: r; Lonicera nigra [6] 7: r; Gentiana asclepiadea [6] 7: r; Sorbus aucuparia [5] 7: r; Pinus sylvestris [5] 8: +; Platanthera bifolia [6] 8: r; Lonicera alpigena [6] 8: r; Rubus hirtus [6] 8: r; Peucedanum austriacum [6] 9: +; Veronica teucrium s. pseudochamaedr [6] 9: +; Cirsium erisithales [6] 9: r; Euphorbia carniolica [6] 9: r; Lonicera xylosteum [6] 9: r; Ulmus glabra [6] 9: r; Luzula luzuloides [6] 11: r; Pinus sylvestris [3] 12: 1; Fraxinus ornus [3] 12: +; Vincetoxicum hirundinaria [6] 12: r; Sanicula europaea [6] 12: r; Potentilla micrantha [6] 12: r; Cardamine pentaphyllos [6] 13: 1; Euphorbia cyparissias [6] 13: +; Galium sylvaticum [6] 13: r; Myosotis sylvatica [6] 13: r; Geranium robertianum [6] 13: r; Maianthemum bifolium [6] 13: r; Carex sylvatica [6] 13: r; Campanula glomerata [6] 13: r; Verbascum nigrum [6] 13: r; 
Urtica dioica [6] 13: r; Erica herbacea [6] 15: 2; Rodendron hiirstum [6] 15: 2; Calamagrostis varia [6] 15: +; Hepatica nobilis [6] 16: r; Melica nutans [6] 18: r; Abies alba [6] 18: r; Asplenium trichomanes-ramosum [6] 18: r; Lonicera alpigena [5] 19: r;

The most common species that appear (up to $50 \%$ frequency) in the whole area are in the Table no. 3:

Table 3. - Species appearance frequency up to $50 \%$.

Tabela 3. - Učestalost javljanja vrsta do $50 \%$.

(Legend: single-digit numbers mark the floor-designation as in Table no. 2; two-digit numbers mark the frequency of appearance, markings in superscripts mark the range of appearance of cover-abundance of Braun-Blanquet scale)

(Legenda: jednocifreni brojevi označavaju spratovnost kao iz tabele br. 2; dvocifreni brojevi označavaju frekvenciju javljanja, oznake u eksponentu označavaju raspon javljanja brojnosti $i$ pokrovnosti Braun-Blanquet skale)

Fagus sylvatica

Fagus sylvatica

Anemone trifolia

Helleborus niger

Picea abies

Picea abies

Festuca altissima

Cyclamen purpurascens

Larix decidua

Hieracium murorum

Euphorbia amygdaloides

Prenanthes purpurea

Mycelis muralis

Based on data from Table no. 3 we can state that in the whole area, the usually constantly present are: Fagus sylvatica, Anemone trifolia, Helleborus niger, Picea abies, Festuca altissima, Cyclamen purpurascens...

However, if we look in detail into Table no. 2, we can notice that left side of the table shows grouping of plots no.: 13, 07, 19, 10, 18, 11, 14, 15, 06, 17, 16, i.e. districts: Bärental/Matschachergupf, Bärental, Zellwinkel, Zell Pfarre, Gotschuchen. Right side of the table is experimental plots no.: 9, 12, 1, and 8, i.e. plots from districts: Waidisch/Outschar, Waidisch/Herperschnig. Central section between mentioned groups is plots no. 3, 4, 2, 5, i.e. plots from districts: Sinachergupf, Tomaschwald. Separation of mentioned groups is visible based on appearance of certain species from the table.

Therefore,"left"side of the Table 2 is the group of experimental plots $(13,07$, $19,10,18,11,14,15,06,17,16)$ that are pronouncedly separated by appearance of: European larch trees (Larix decidua), and species of ground flora: Cardamine trifolia, Cardamne ennephyllos, Lamium galeobdelon, Senetio germanicus, Oxalis acetosela, Veronica urticifolia. The right side of the Table 2 is the second group of species: in 

alps (Austria)

tree floor: Pinus sylvestris and Sorbus aria, and floor of ground flora of species: Cephalanthera rubra, Salvia glutinosa, Fraxinus excelsior, Dryopteris sp.

Similar distribution of experimental plots as in Table 2 we have in Graph no. 1. Experimental plots no.: 9, 8, 1, and 12 take the right side of coordinate system.

Left side of coordinate system of Graph no. 1 includes plots no.: 13, 7, 19, 10, $18,11,14,15,06,17$, and 16 that make a first group of plots. Right side includes the second group of plots $9,8,1,12$. Intermediary closer to center of coordinate system are plots no. 3,4,5. Plot no. 2 that is intermediary in Table no. 2, in Graph 1 is moved to the left and mixed with other plots of the left side of coordinate system.

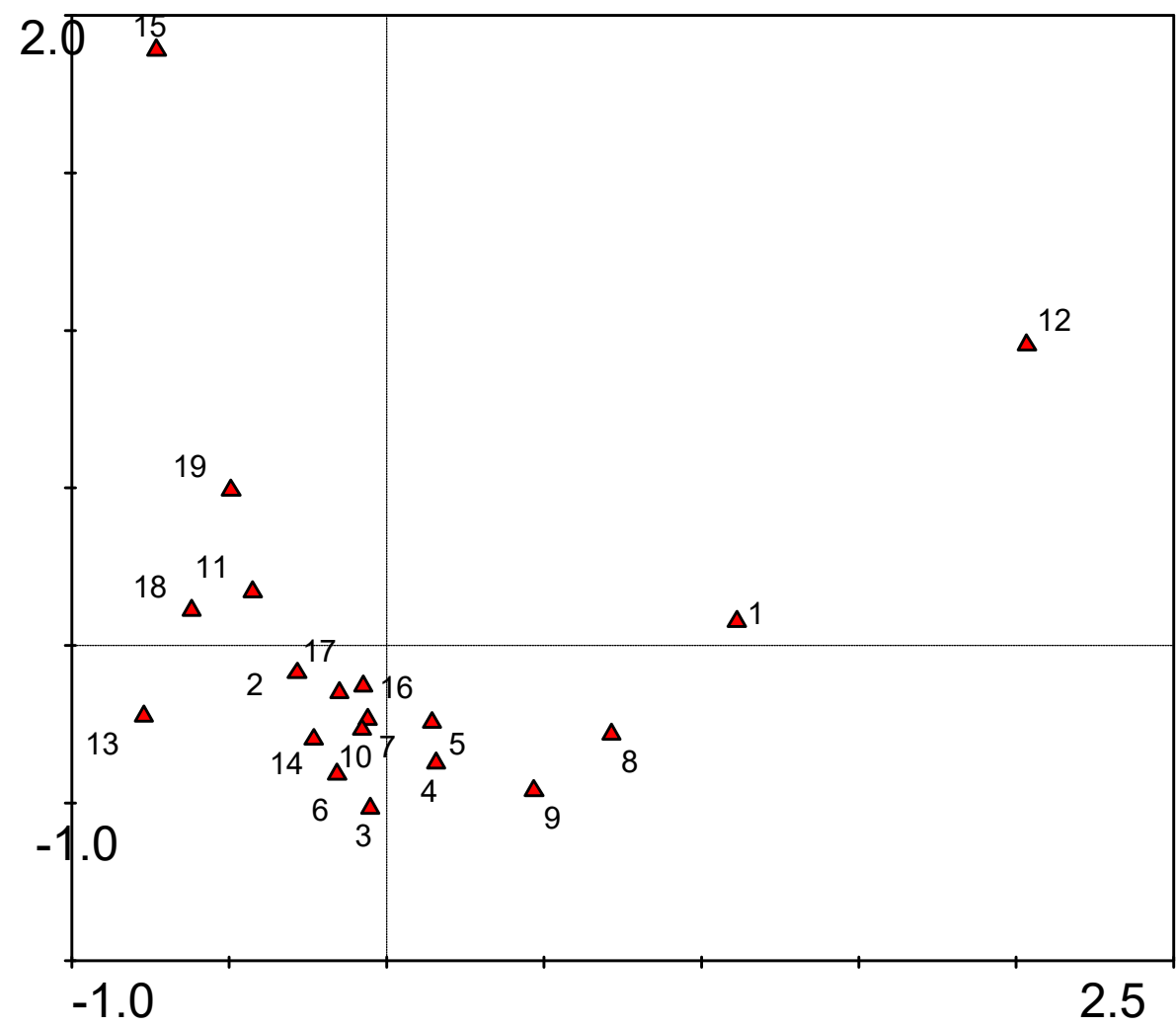

Graph. 1 - CA ordinate biplot for analyzed area Graf. 1 - CA ordinacijski biplot za analizirano područje (Legend: Numbers in coordinate system represent numbers of experimental plots) (Legenda: Brojevi u koordinatnom sistemu predstavljaju brojeve eksperimentalnih ploha) 


\section{Phytogeographic affiliation - Fitogeografska pripadnost}

Based on phytocenologicalanalysis i.e. synthetic table, and CA ordinate biplot, groups of experimental plots were formed. The first group contains plots no.: 13, 7 , $19,10,18,11,14,15,06,17$, and 16 ; the second contains plots $9,12,1$, and 8 ; and the third contains plots no: $3,4,2$, and 5. According to these groups we made analysis of phytogeographic affiliation to determine participation of appropriate flora geoelements. Also, for each group we analyzed the frequency of appearance of each individual species, to determine with which percentage of appearance each individual species participate in total number of plots.

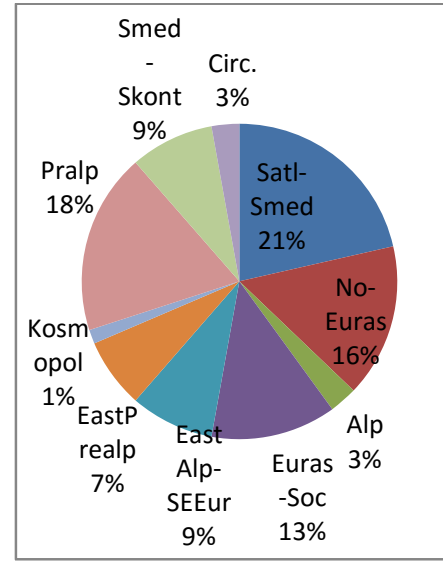

Graph 2. - Phytogeographic affiliation of species of the first group (for plots 13, 7, 19, 10, $18,11,14,15,06,17$, and 16) i.e.

Bärental/Matschachergupf, Bärental, Zellwinkel, Zell Pfarre, Gotschuchen.

Graf 2. - Fitogeografska pripadnost vrsta prve skupine (za plohe 13, 7, 19, 10, 18, 11, $14,15,06,17,16)$ odnosno revira:Bärental/Matschachergu pf, Bärental, Zellwinkel, Zell Pfarre, Gotschuchen.

(Legend: Smed-Skont $=$ Sub-Mediterranean-Subcontinental; Pralp=Pre-Alpine; Kosmopol=Cosmopolitan; EastPralp= Eastern Pre-Alpine; East Alp-SEEur=Eastern Alpine-South East European (Meta-Illyrian); Euras-Soc $=$ Eurasian-Sub-oceanic; Alp=Alpine; No-Euras=Northern Eurasian; Satl-Smed=Sub-AtlanticSub-Mediterranean; Circ $=$ Circum-Polar)

(Legenda: Smed-Skont=Submediteranske-Subkontinetalne; Pralp=Prealpske; Kosmopol=Kosmopolitske; EastPralp= Istično Prealpske; East Alp-SEEur=Istočno Apske-Južno istočno Evropske (Metailirske); Euras-Soc $=$ Euroazijske-Suboceanske; Alp=Alpske; No-Euras=Sjeverno Euroazijske; SatlSmed $=$ Subatlansko-Submediteranske; Circ=Cirkumpolarne)

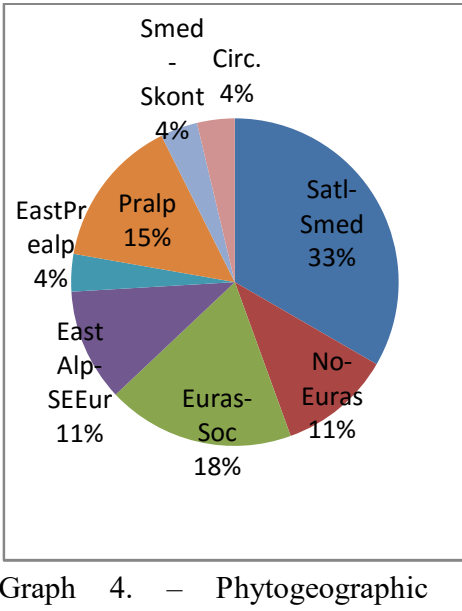
affiliation of species of the third group (for plots $3,4,2$, and 5) i.e. districts: Sinachergupf, Tomaschwald.

Graf 4. - Fitogeografska pripadnost vrsta treće skupine (za plohe 3, 4, 2, 5) odnosno revira: Sinachergupf, Tomaschwald. 


\section{DISCUSSION - Diskusija}

Analysis of gathered phytocenological records (Table 2) has shown that in a large part of analyzed area we find eastern Alpine beech communities. Floristic composition shows that these Alpine beech forests are located on the border with Illyrian province. Although in analyzed forests we find species that in literature are treated as eastern Alpine and southeast-European flora elements ${ }^{2}$ (i.e. as meta-Illyrian species) for example: Anemone trifolia, Cardamine trifolia, Cardamne ennephyllos, Aposeris foetida, Cyclamen purpurascen, these Alpine beech communities show significant deflection from - difference related to real Illyrian beech forests. MetaIllyrian species are not distinctively Illyrian species but species of the wider amplitude of appearance that are appearing in wider area surrounding Illyrian province (for example Anemone trifolia apears in southern and central Europe to the west all the way to Portugal, to the north to Finland ${ }^{3}$, etc...). Particular authors call species of wider Illyrian distribution as Illyricoid (TRINAJSTIĆ, 1997). Their appearance in Alpine area can be explained with their broader ecological amplitude.

In floristic sense one spots difference in absence of typical and distinct Illyrian species, for example: Cardamine kitaibelii, Cardamine waldsteinii, Omphalodes verna, Haqcuetia epipactis, Vicia oroboides, Scopolia carniolica, Calamintha grandiflora (STEFANOVIĆ, 1986). Besides typical representatives of ground flora that are missing, in this area is also noticeable absence of specific Illyrian representatives of beech forests from bush floor: Rhamnus fallax, Daphne laureola and Euonimus latifolia. Usually bush floor of type Aremonio-Fagionis far more developed, so more frequent, than in analyzed area, the species Lonicera alpigena, Lonicera xylosteum, Lonicera nigra (BEUS et VOJNIKOVIĆ, 2002) appear. Almost complete absence of grown bush floor shows less expressed floor-designation, unlike Illyrian beech forest where floor-designation in mixed forests with beech, fir and spruce is expressed.

Particularly large difference is represented in appearance of European larch (Larix decidua), which is not represented in forests Aremonio-Fagion. In analyzed area European larch appeared with participation of 58\% of all plots (table 3). Appearance of this species is very significant considering that European larch is included into Alpine mountain-Carpathian sub-mountain and Sudeten sub-mountain flora element. In specific case, in analysis area this species presents special landmark to mentioned forests in a sense of looks/appearance and structure because it represents (sub) edificator species. Factually Larix deciduas species is naturally distributed in Alpine, and not in Illyrian flora area. Appearance of European larch shows also completely different succession development of Alpine beech forests in relation to Illyrian. Description of succession development of Illyrian beech forest was described by STEFANOVIĆ (1960) (Scheme 1).

\footnotetext{
${ }^{2}$ Oberdorfer (1994) treated them as (east) (pre)-alpine.

${ }^{3}$ Flora Europaea Search Results (www.http://rbg-web2.rbge.org.uk/FE/fe.html).
} 
In analyzed area in larger part (except in district Waidisch/Outschar, Waidisch/Herperschnig) there is absence of appearance of typical transition stages that are characteristic to Illyrian beech forests of the type Aremonio-Fagion for example: Piceo-Pinetum Illyricum, Populi-Betuletumtypicumas well as of terminal phase AbietiPicetum. Mentioned should be linked with appearance of European larch, which as heliophile species in Alpine area takes place of Scots pine, a heliophile species typical for succession in Illyrian area.This difference shows different habitat characteristics above all in mesophile type of habitat, because European larch seeks significantly more mesophile habitats than the Scots pine. Mentioned points that directions and stages i.e. phases of emergence of beech forests in Alpine and Illyrian area are completely different, i.e. have different point of origin. Mentioned strongly points that, beside appearance of individual "meta-Illyrian species", Alpine and Illyrian beech forests are in its base different, which is noticeable also in analyzed area.

According to this author succession development of Illyrian beech forest takes place as follows:

In syntaxonomy sense based on phytocenologicalrecords (Table 2.) in analyzed area is possible to separate two associations, whereby one association (Anemone trifoliae - Fagetum) has two sub-associations:

- Group one, districts: Bärental/Matschachergupf, Bärental, Zellwinkel, Zell Pfarre, and Gotschuchenthat covers plots no.: 13, 7, 19, 10, 18, 11, 14, 15, 06, 17, and 16 can come under association of beech and European larch: Anemone trifoliae - Fagetum laricetosum TREGUBOV 1957. (syn.: Larici - Fagetum Robič 1971 /n.nudum./ and syn.: Fagetum subalpinum var. geogr. Larix decidua MARINČEK, POLDINI, ZUPANČIČ 1986.)

- Group two, districts: Waidisch/Outschar, Waidisch/Herperschnig plots no.: 9, 12,1 , and 8 which is the closest (depleted variant) to "Illyrian" beech-fir spruce forest association Salvio glutinosae - Fagetum.

- Group three, districts: Sinachergupf, Tomaschwald for plots 3, 4, 2, and 5 as typical community Anemone trifoliae - Fagetum typicum TREGUBOV 1957 var. Carex alba MARINČEK, POLDINI, ZUPANČIČ 1986.

- Considering that in Graph 1 both sub-associations laricetosum and typicum of association Anemone trifoliae - Fagetum are close, i.e. they connect; further in text they will be processed together within association Anemone trifoliae Fagetum. Different authors unanimously place community Anemone trifoliae - Fagetum into "ALPINE WORLD" although syntaxonomy placement of this association in hierarchy system is different: 

alps (Austria)

Table 4. - Sintaxonomy affiliation of association Anemone trifoliae - Fagetum

Tabela 4. - Sintaksonomska pripadnost asocijacije Anemone trifoliae - Fagetum

\begin{tabular}{|l|l|l|l|l|}
\hline Author/s & $\begin{array}{c}\text { According to: } \\
\text { Tregubov } \\
\text { (Zukrigl, 1988) }\end{array}$ & $\begin{array}{l}\text { According to } \\
\text { Smole (1988) }\end{array}$ & $\begin{array}{c}\text { According to: } \\
\text { Willner (2002) }\end{array}$ & $\begin{array}{l}\text { According to: } \\
\text { Willner, W., } \\
\text { Grabherr, G. } \\
\text { (2007) }\end{array}$ \\
\hline Alliance & $\begin{array}{l}\text { Fagion } \\
\text { medioeuropaeum }\end{array}$ & $\begin{array}{l}\text { Fagion } \\
\text { illyricum } \\
\text { (Aremonio- } \\
\text { Fagion) }\end{array}$ & Asperulo-Fagion & $\begin{array}{l}\text { Fagion } \\
\text { sylvaticae }\end{array}$ \\
\hline $\begin{array}{l}\text { Sub- } \\
\text { alliance }\end{array}$ & & & $\begin{array}{l}\text { Lonicero - } \\
\text { Fagenion }\end{array}$ & $\begin{array}{l}\text { Lonicero - } \\
\text { Fagenion }\end{array}$ \\
\hline
\end{tabular}

Out of mentioned authors the best expert of Illyrian beech forests is TREGUBOV who in 1941. in doctor thesis: "Le Foret vierges montagnardes des Alpes Dinariques. Massive Klekovatcha et Grmetch" was the first to research phytocenologically and described Illyrian beech and fir forests in Bosnia. Also, this author worked and described Alpine beech forests in Slovenia (1957) and spotted differences and communities between Alpine and Illyrian beech forests and community Anemone trifoliae - Fagetum (which he "de facto"described first), and placed them it in Central European beech alliance.

Understanding of SMOLE (1988) is questionable, because, on one side, he places community into "Alpine world", and, on other side, places it into Illyrian type of forests, which is by itself contradictory. Illyrian and Alpine floral province are neighboring but do not overlap. Completely wrong is his understanding that exclusively appearance of meta-Illyrianspeciesis the condition to place them into Illyrian group of forests. Appearance of these forests is expected considering the neighboring Illyrian province. At this mentioned one did not analyze absence of typical Illyrian species, different structures as well as completely different syndynamics of occurrence of Illyrian from Alpine beech forests, as well as the very area linked to Alpine mountainous area.

Initial understanding of WILLNER (2002) was that community Anemone trifoliae - Fagetum belongs to group Asperulo-Fagion, so that later together with GRABHERR (2007) he would change his stand and place this community into group: Fagion sylvaticae. Such understanding of placing this community into Central European group of beech forests is justified. However, in understanding of WILLNER et GRABHERr (2007) it is not clear, i.e. what is confusing is how community association Anemone trifoliae - Fagetum of mentioned group Fagion sylvaticaehe placed into code $91 \mathrm{~K} 0$. Code $91 \mathrm{~K} 0$ in Natura 2000 is defined as group Aremonio-Fagion. In this way WILLNER et GRABHERR (2007) are 
factually at the same time placing community Anemone trifoliae - Fagetumin two synsystematic units of the same rank (i.e. alliance): Fagion sylvaticae and Aremonio-Fagion which is unacceptable according to International Code of Phytosociological Nomenclature - ICPN (WRABER et al. 2000). Besides mentioned, WILLNER (2002) also states that area of this community is distributed over whole Southern Alps, whereby this community is geographically excluded from the Illyrian area.

We should mention that not a single literature source from Bosnia and Herzegovina and Croatia states the existence of community Anemomo trifoli Fagetumin these countries. Out of the countries in which we find Illyrian province, this community is registered only in Slovenia and Austria in Alpine area. Mentioned also points out that this community does not appear in typical Illyrian area related to Western Balkans, but exclusively in Alpine phytogeographic area that as we mention borders with, but does not represent Illyrian province.

Community Salvio glutinosae - Fagetum ZUKRIGL 1988 is in Graph 1 and Table 2 in flora sense clearly separated from community Anemone trifoliae Fagetum. This community looks the most like Illyrian mixed beech forests, i.e. they represent their "depleted variant". Particularly standing out is absence of European larch and appearance of Scots pine within community, which points to similar syndynamic development of this community as in Illyrian area. In this community out of typical Illyrian species we noticed species: Aremonia agrimonoides with appearance frequency of 50\%. Research conducted in Bosnia (BEUS et VOJNIKOVIĆ, 2002) show that appearance of this speciesis above $75 \%$. We should mention that these species in community Anemone trifoliae - Fagetum during this research was not registered at all. Appearance of Scots pine as well as species Sorbus aria and Cephalanthera rubra points to more thermophile habitat conditions related to community Anemone trifoliae - Fagetum, whereby this community is also closing to Illyrian group of beech forests Natura 2000 of code $91 \mathrm{~K} 0$. 


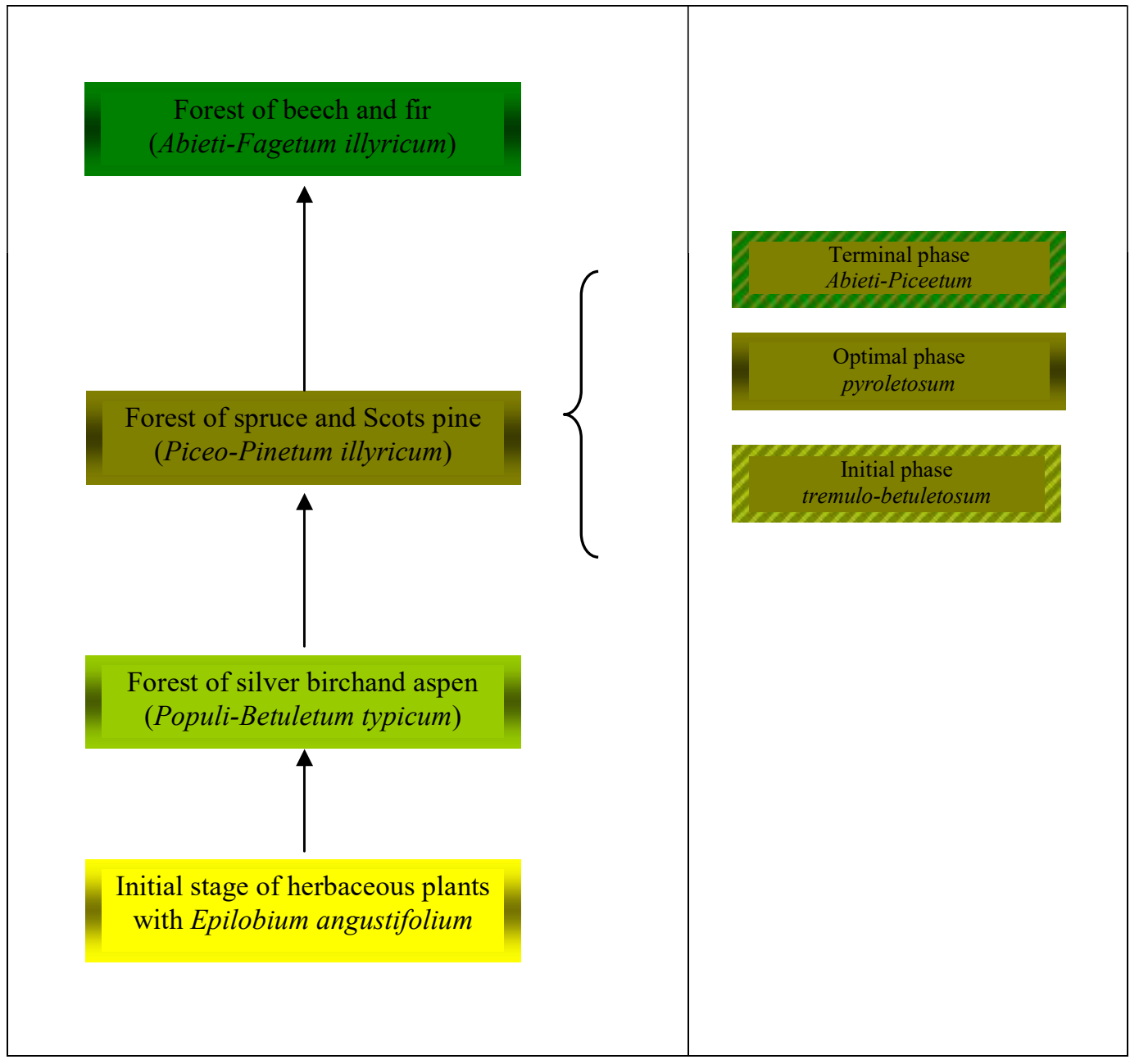

Scheme - 1.: Progression succession scheme of mixed Illyrian beech forest on carbonate base (Stefanović, 1960)

Shema - 1.: Progresiona sukcesiona shema ilirske mješovite bukove šume na karbonatnoj podlozi (Stefanović, 1960)

From Graphs 2, 3 and 4 we notice that participation of speciescalled Eastern Alpine-South East European (meta-Illyrian) for all associations i.e. sub-associations amounts approximately the same 8, 10, $11 \%$.These meta-Illyrianspecies were mentioned earlier. However, there is noticeable difference of Alpine and Northern i.e. Sub-Mediterranean - subcontinental and sub-oceanic geo-florist from Graphs 2, 3 and 4 that shows geo-florist character of community Anemone trifoliae - Fagetum laricetosum and Anemone trifoliae - Fagetum typicum in relation to community Salvio glutinosae - Fagetum. 
Table 5. - Percentage participation of groups of flora geo-elements per communities Tabela 5. - Procentualno učešće skupina flornih geoelemenata po zajednicama

\begin{tabular}{|l|c|c|c|}
\hline $\begin{array}{l}\text { Participation of groups of } \\
\text { geo-florist elements }\end{array}$ & $\begin{array}{c}\text { Anemono trifolio- } \\
\text { Fagetum } \\
\text { laricetosum }\end{array}$ & $\begin{array}{c}\text { Anemono trifolio } \\
- \text { Fagetum } \\
\text { typicum }\end{array}$ & $\begin{array}{c}\text { Salvio } \\
\text { glutinosae - } \\
\text { Fagetum }\end{array}$ \\
\hline Alpine and Northern & $45 \%$ & $34 \%$ & $32 \%$ \\
\hline $\begin{array}{l}\text { Sub-Mediterranean - } \\
\text { subcontinentaland sub- } \\
\text { oceanic }\end{array}$ & $43 \%$ & $55 \%$ & $56 \%$ \\
\hline
\end{tabular}

Certainly the most distinct difference per geo-florist spectrum shows two communities that in Graph 1 and in Table 2 showed the largest difference i.e. their character. Participation of cold northern species (Table 5) is largest in community Anemono trifolio - Fagetum laricetosum, while participation of 'warm-loving' and Sub-Mediterranean species was noticed in community Salvio glutinosae - Fagetum. Intermediary place has the community Anemono trifolio - Fagetum typicum with somewhat little participation of 'warm-loving' species which is understandable because it is var. Carex alba, which by itself is 'warm-loving'.

Actually it is seen that appearance of meta-Illyrian speciesis not essential to characterize traits of mentioned communities but appearance of Northern and Alpine i.e. thermophileand Sub-Mediterranean species.

\section{CONCLUSIONS - Zaključci}

Conducted research on 19 experimental plots in the Karawanke area of Forstverwaltung Hollenburg showed the following:

1. Although in analyzed forests we find speciesthat in literature are treated as Eastern Alpineand South East European flora elements (i.e. as meta-Illyrian species) for example: Anemone trifolia, Cardamine trifolia, Cardamne ennepahyllos, Aposeris foetida, Cyclamen purpurascen, these Alpine beech communities show significant difference in relation to the real Illyrian beech forests.

2. In floristic sense we notice the difference in absence of typical and distinct Illyrian speciesfor example: Cardamine kitaibelii, Cardamine waldsteinii, Omphaloides verna, Haquetia epipactis, Vicia oroboides, Scopolia carniolica, Calamitha grandiflora. Besides typical representatives of ground flora that are

\footnotetext{
${ }^{4}$ Covers groups of flora geo elements: pre-Alpine + Alpine + Eastern Alpine + Northern Eurasian + circum polar

${ }^{5}$ Covers groups of flora geo elements: sub-mediterranean-subcontinetal + eurasian-suboceanic

+ sub-atlantic-sub.mediterranean + eastern mediterranean + sub-mediterranean
} 

alps (Austria)

missing, in this area we also notice absence of individual Illyrian representatives of beech forests from bush floor: Rhamnus fallax, Daphne laureola and Evonimus latifolia.

3. Bush floor within typical Illyrian alliance Aremonio-Fagionis far more developed. So more often the non-Illyrian speciesof bushes appear, for example: Lonicera alpigena, Lonicera xylosteum, Lonicera nigra than it is the case in analyzed area. General floor-distinction in typical Illyrian beech forests is far more developed than in Alpine.

4. In analyzed area European larch appeared with frequency of $58 \%$ of all plots. Species Larix deciduas is naturally distributed in Alpine, and not in Illyrian flora area. Appearance of European larch shows the completely different syndynamic (succession) development of Alpine beech forests in relation to Illyrian. Larix decidua represents (sub) edificator species in community therefore has a higher specific weight than meta- Illyrian species in phytographic meaning.

5. In analyzed area in larger part (except in districts Waidisch/Outschar, Waidisch/Herperschnig) lacks the appearance of typical transition stages which are characteristic to Illyrian beech forests of group Aremonio-Fagion for example: Piceo-Pinetum illyricum, Populi-Betuletum typicum as well as terminal phases of development of these forests Abieti-Picetum. This difference shows different habitat characteristics above all in mesophile character of habitat, because European larch seeks more mesophile habitats than Scots pine. Mentioned points that directions and stages i.e. phases of occurrence of beech forests in Alpine and Illyrian area are completely different, i.e. have different point of origin i.e. succession series.

6. In syntaxonomy sense based on phytocenological records in analyzed area it is possible to separate two associations (out of which one with two subassociations).

- Anemone trifoliae - Fagetum laricetosum TREGUBOV 1957. (syn.: Larici Fagetum ROBIČ 1971 /n.nudum./ and syn.: Fagetum subalpinum var. geogr. Larix decidua MARINČEK, POLDINI, ZUPANČIČ 1986.), within district: Bärental/Matschachergupf, Bärental, Zellwinkel, Zell Pfarre, and Gotschuchenwhich covers plots no: 13, 7, 19, 10, 18, 11, 14, 15, 06, 17, and 16.

- Anemone trifoliae - Fagetum typicum TREGUBOV 1957 var. Carex alba MARINČEK, POLDINI, ZUPANČIČ 1986. within district: Sinachergupf, Tomaschwald that covers plots 3, 4, 2, and 5 .

- Salvio glutinosae - Fagetum ZUKRIGL 1988 within two districts: Waidisch/Outschar, Waidisch/Herperschnig plots no: 9, 12, 1, and 8.

7. Community Anemono trifoliae - Fagetum according to: TREGUBOV (1957), WILLNER (2002) and WILLNER et GRABHERR (2007) belongs to group of Central European beech forests: Fagion sylvaticae (Syn.: Fagion medioeuropaeum et Syn.: Asperulo - Fagion). Respecting IPCN mentioned, 
automatically one excludes possibility of placing this community also in a group of Illyrian beech forests Aremonio-Fagion (Natura 2000 of Code 91K0), which was wrongly mentioned in WILLNER et GRABHERR (2007), because one association cannot be placed into two alliances.

8. Out of mentioned so far comes the conclusion that forest area within districts of Forstverwaltung Hollenburg: Bärental/Matschachergupf, Bärental, Zellwinkel, Zell Pfarre, Gotschuchen Sinachergupf, Tomaschwald do not belong to Illyrian group of beech forests Aremonio-Fagion Natura 2000 of code $91 \mathrm{~K} 0$, but to code 9130 (Central European beech forests) in accordance with Natura 2000.

9. Community Salvio glutinosae - Fagetum ZUKRIGL 1988 within districts: Waidisch/Outschar, Waidisch/Herperschnig, although floristically poorer shows the most similarity but not fully identity with illyrian beech forests Aremonio-Fagion (Natura 2000 of Code 91K0).

\section{REFERENCES - Literatura:}

ADAMOVIĆ, L. (1907): Die pflanzengeographische Stellung und Gliederung der Balkanhalbinsel. Resultate einer im Sommer 1905 in den Balkanländern unternommenen Reise, die von der Kaiserlichen Akademie der Wissenschaften aus der Treitl-Stiftung subventioniert wurde. Staatsdruckerei, Wien.

BECK G. (1901): Die Vegetationsverhältnisse der illyrischen Länder, begreifend Sudcroatien, die Quarnero-Inseln, Dalmatien, Bosnien und die Hercegovina, Montenegro, Nordalbanien, den Sandzak Novipazar und Serbien. Leipzig, Verlag von Wilhelm Engelmann, map supplement. (Die Vegetation der Erde, vol. 4.).

BEUS, V., VOJNIKOVIĆ S. (2002): Floristical characteristics of the virgin Forest of Beech and Fir in Ravna vala on Mt. Bjelašnica, Razprave IV. Razreda SAZU, Ljubljana.

BLAMEY, M., GREY-WILSON, C. (2008): Die Kosmos Enzyklopädie der Blütenpflanzen, Fracnch-Kosmos Verlags-GmbH \& Co. KG, Stuttgart.

BRAUN-BLANQUET,J. (1964): Pflanzensoziologie, Grundzüge der Vegetationskunde. (3. Auflage). Springer Verlag, Wien

BRAAK, C. J. F. AND ŠMILAUER, P. (2002). CANOCO Reference Manual and CanoDraw for Windows User's Guide: Software for Canonical Community Ordination (version 4.5). Microcomputer Power (Ithaca NY, USA), 500 pp.

FUKAREK P. (1978): Verbretitungsgebiete einiger charakterarten der slowenischen und kroatischen buchenwäledr und ihre bedeutung für regionale gliederung dees dinarishcen florengebietes. Mitteil. Ostalp-dinar Ges. Vegetationsk. 14, Ljubljana.

FUKAREK, P. (1980): Geografija šuma. Šumarska enciklopedija - I, Jugoslavenski Leksikografski Zavod, Zagreb. 
HENNEKENS, S.M., SCHAMINEE, J.H.J. (2001). Turboveg, a comprehensive database management system for vegetation data Journal of Vegetation Science 12: 589-591.

HORVAT, I., GLAVAČ, V., ELLENBERG, H. (1974): Vegetation Südosteuropas. Gustav Fischer Verlag, Stuttgart.

LAUBER, K., WAGNER, G. (2001): Flora Helvetica 2.0, CD - ROM, Ein interaktiv Führer durch die Pflanzwelt der Schweiz, Haupt digital.

MAYER, H. (1986): Europäische Wälder. Gustav Fischer Verlag, Stuttgart, New York.

OBERDORFER, E. (1994): Pflanzen-soziologische Exursionsflora; Verlag Eugen Ulmer, Stuttgart.

SMOLE, I. (1988): Katalog gozdnih združb Slovenije, Inštitut za gozdno in lesno gospodarstvo, Ljubljana.

STEFANOVIĆ, V. (1960): Tipovi šuma bijelog bora na području krečnjaka istočne Bosne; Naučno društvo Bosne i Hercegovine, Odjeljenje privredno-tehničkih nauka Knj. 4, Radovi, knj. XVI, Sarajevo, 82-142.

STEFANOVIĆ, V. (1986): Fitocenologija sa pregledom šumskih fitocenoza Jugoslavije, Svjetlost, Sarajevo.

ŠiLiĆ, Č. (1990): Šumske zeljaste biljke. Svjetlost, Sarajevo.

THOMMEN, E. (1973): Taschenatlas der Schweizer Flora; Birkhauser Verlag, Basel und Stuttgart.

TREGUBOV V. (1941): Le Foret vierges montagnardes des Alpes Dinariques. Massive Klekovatcha et Grmetch, mnsc. Doctoral thesis. Monpelier.

TREGUBOV V. et coll. (1957): Prebiralni gozdovi na Snežniku. Strok. Znanstv. dela, Inštitut za gozdno in lesno gospodarstvo, Ljubljana.

TRINAJSTIĆ, I. (1997): Phytogeographical analysis of the illyricoid floral geoelement. - Acta Biologica Slovenica 41(2/3): 77-85.

TICHÝ L. (2002): JUICE, software for vegetation classification. - Journal of Vegetetion Science13. Opulus Press, Uppsala, pp.: 451-453.

WILLNER, W. (2002): Syntaxonomische Revision der südmitteleuropäischen Buchenwälder, Phytocoenologia, 32(3), Berlin-Stuttgart, pp. 337-453.

WiLLNER, W., GRABHERR, G. (2007): Die Wälder und Gebüsche Österreichs. Elsevier, München.

WRABER, H.E., MORAVEC, J., THEURILLAT, J.-P (2000): International Code of Phytosociological Nomenclature, Journal of Vegetation Sciencel 1: 739-768

ZUKRIGL, K. (1988): Die Montanen Buchenwälder der Österreischen südalpen (Karawanken und Karnische Alpen), Sauteria 4.pp 11-16. 


\section{SAŽETAK}

Položaj ilirske vegetacijske provincije na zapadnom Balkanu utvrđen je davno (npr.: BECK, 1901, ADAMOVIĆ 1907...) Ilirski prostor se veže za: Crnu Goru, Bosnu i Hercegovinu, Hrvatsku i Sloveniju. Karavanke predstavljaju granicu između Austrije i Slovenije ali također predstavljaju i granično područje ilirske provincije. Utvrđivanje fitogeografske pripadnosti šumskih zajednica bukve postaje veomo važno sa aspekta zaštite u smislu Nature 2000. Prema zahtjevima Nature 2000 ilirske bukove šume (91K0 - sveza: Aremonio - Fagion), predstavljaju šume od interesa za zaštitu u Austriji. S toga je važno utvrditi vegetacijsko - florističke karakteristike bukovih šuma na Karavankama, na osnovu čega bi se moglo zaključiti njihova fitogeografska pripadnost. Sprovedenim istraživanjem unutar bukovih šuma na području šumarije Hollenburg utvrđeno je postojanje sljedećih zajednica bukve: Anemone trifoliae Fagetum laricetosum TREGUBOV 1957. (syn.: Larici - Fagetum ROBIČ 1971 /n.nudum./ i syn.: Fagetum subalpinum var. geogr. Larix decidua MARINČEK, POLDINI, ZUPANČIČ 1986.); Anemone trifoliae - Fagetum typicum TREGUBOV 1957 var. Carex alba MARINČEK, POLDINI, ZUPANČIČ 1986; Salvio glutinosae Fagetum ZUKRIGL, 1988. Na osnovu florističkih karakteristika, njihove strukture, sindinamike, može se zaključiti da prve dvije zajednice se ne mogu svrstati u ilirske bukove šume, dok zajednica Salvio glutinosae -Fagetum pokazuje sličnost sa ilirskim bukovim šumama sveze Aremonio-Fagion (Natura 2000 kod 91K0).

ANNEXES:

Map 1

Map 2

Tables 


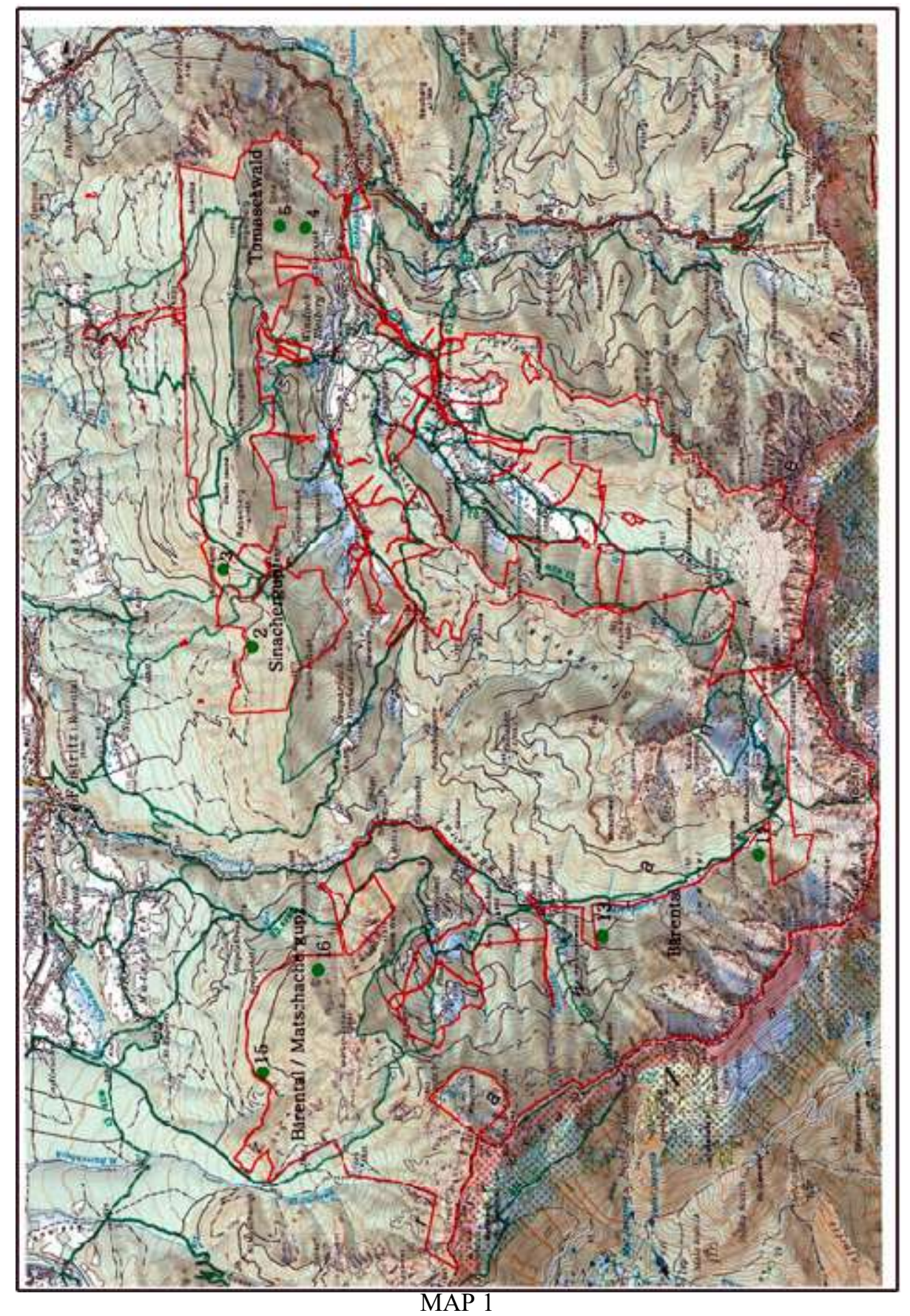




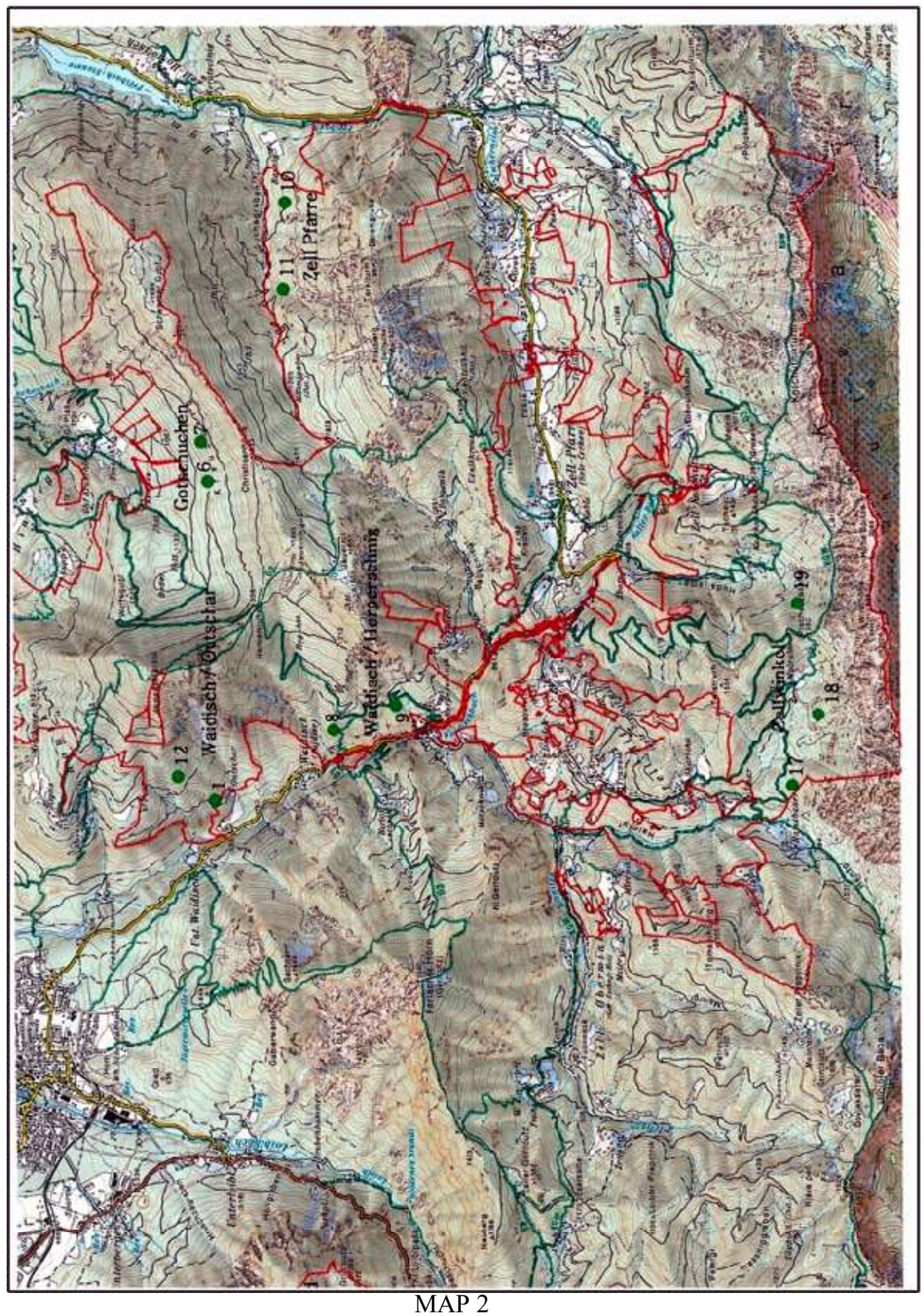



alps (Austria)

\begin{tabular}{|c|c|c|c|c|c|c|c|c|c|}
\hline$\Rightarrow$ & $\Rightarrow$ & $\Rightarrow$ & $\Rightarrow$ & $\Rightarrow$ & $\Rightarrow$ & $\Rightarrow$ & $\Rightarrow$ & $\Rightarrow$ & $\Rightarrow$ \\
\hline $\begin{array}{l}\text { Relevé } \\
\text { number: } \\
1\end{array}$ & $\begin{array}{l}\text { Relevé } \\
\text { number: } \\
2\end{array}$ & $\begin{array}{l}\text { Relevé } \\
\text { number: } \\
3\end{array}$ & $\begin{array}{l}\text { Relevé } \\
\text { number: } \\
4\end{array}$ & $\begin{array}{l}\text { Relevé } \\
\text { number: } \\
5\end{array}$ & $\begin{array}{l}\text { Relevé } \\
\text { number: } \\
6\end{array}$ & $\begin{array}{l}\text { Relevé } \\
\text { number: } \\
7\end{array}$ & $\begin{array}{l}\text { Relevé } \\
\text { number: } \\
8\end{array}$ & $\begin{array}{l}\text { Relevé } \\
\text { number: } \\
9\end{array}$ & $\begin{array}{l}\text { Relevé } \\
\text { number: } \\
10\end{array}$ \\
\hline $\begin{array}{l}\text { Country } \\
\text { code } \\
\text { : Austria }\end{array}$ & $\begin{array}{l}\text { Country } \\
\text { code } \\
\text { : Austria }\end{array}$ & $\begin{array}{l}\text { Country } \\
\text { code } \\
\text { : Austria }\end{array}$ & $\begin{array}{l}\text { Country } \\
\text { code } \\
\text { : Austria }\end{array}$ & $\begin{array}{l}\text { Country } \\
\text { code } \\
\text { : Austria }\end{array}$ & $\begin{array}{l}\text { Country } \\
\text { code } \\
\text { : Austria }\end{array}$ & $\begin{array}{l}\text { Country } \\
\text { code } \\
\text { : Austria }\end{array}$ & $\begin{array}{l}\text { Country } \\
\text { code } \\
\text { : Austria }\end{array}$ & $\begin{array}{l}\text { Country } \\
\text { code } \\
\text { : Austria }\end{array}$ & $\begin{array}{l}\text { Country } \\
\text { code } \\
\text { : Austria }\end{array}$ \\
\hline $\mathrm{Nr}$. & & $\mathrm{Nr}$. & $\mathrm{Nr}$. & & $\mathrm{Nr}$. & $\mathrm{Nr}$. & & $\mathrm{Nr}$. & $\mathrm{Nr}$. \\
\hline $\begin{array}{l}\text { relevé in } \\
\text { table }\end{array}$ & $\begin{array}{l}\text { relevé in } \\
\text { table }\end{array}$ & $\begin{array}{l}\text { relevé in } \\
\text { table }\end{array}$ & $\begin{array}{l}\text { relevé in } \\
\text { table }\end{array}$ & $\begin{array}{l}\text { relevé in } \\
\text { table }\end{array}$ & $\begin{array}{l}\text { relevé in } \\
\text { table }\end{array}$ & $\begin{array}{l}\text { relevé in } \\
\text { table }\end{array}$ & $\begin{array}{l}\text { relevé in } \\
\text { table }\end{array}$ & $\begin{array}{l}\text { relevé in } \\
\text { table }\end{array}$ & $\begin{array}{l}\text { relevé in } \\
\text { table }\end{array}$ \\
\hline$: 1$ & $: 2$ & $: 3$ & $: 4$ & $: 5$ & $: 6$ & $: 7$ & $: 8$ & $: 9$ & $: 10$ \\
\hline Cover & Cover & Cover & Cover & Cover & Cover & Cover & Cover & Cover & Cover \\
\hline abundan & abundan & abundan & abundan & abundan & abundan & abundan & abundan & abundan & abundan \\
\hline ce scale & ce scale & ce scale & ce scale & ce scale & ce scale & ce scale & ce scale & ce scale & ce scale \\
\hline$:$ & : & : & : & : & : & : & : & : & : \\
\hline Braun/B & Braun/B & Braun/B & Braun/B & Braun/B & Braun/B & Braun/B & Braun/B & Braun/B & Braun/B \\
\hline $\begin{array}{l}\text { lanquet } \\
\text { (old) }\end{array}$ & $\begin{array}{l}\text { lanquet } \\
\text { (old) }\end{array}$ & $\begin{array}{l}\text { lanquet } \\
\text { (old) }\end{array}$ & $\begin{array}{l}\text { lanquet } \\
\text { (old) }\end{array}$ & $\begin{array}{l}\text { lanquet } \\
\text { (old) }\end{array}$ & $\begin{array}{l}\text { lanquet } \\
\text { (old) }\end{array}$ & $\begin{array}{l}\text { lanquet } \\
\text { (old) }\end{array}$ & $\begin{array}{l}\text { lanquet } \\
\text { (old) }\end{array}$ & $\begin{array}{l}\text { lanquet } \\
\text { (old) }\end{array}$ & $\begin{array}{l}\text { lanquet } \\
\text { (old) }\end{array}$ \\
\hline Date & Date & Date & Date & Date & Date & Date & Date & Date & Date \\
\hline (year/m & (year/m & (year/m & (year/m & (year/m & (year/m & (year $/ \mathrm{m}$ & (year/m & (year/m & (year/m \\
\hline onth/day & onth/day & onth/day & onth/day & onth/day & onth/day & onth/day & onth/day & onth/day & onth/day \\
\hline ) & ) & ) & ) & ) & ) & ) & ) & ) & ) \\
\hline $2015 / 07 /$ & $2015 / 07 /$ & $2015 / 07 /$ & $2015 / 07 /$ & $2015 / 07 /$ & $2015 / 07 /$ & $2015 / 07 /$ & $2015 / 07 /$ & $2015 / 07 /$ & $2015 / 07 /$ \\
\hline 21 & 21 & 21 & 21 & 21 & 22 & 22 & 22 & 22 & 22 \\
\hline Relevé & Relevé & Relevé & Relevé & Relevé & Relevé & Relevé & Relevé & Relevé & Relevé \\
\hline area & area & area & area & area & area & area & area & area & area \\
\hline$(\mathrm{m} 2)$ & $(\mathrm{m} 2)$ & $(\mathrm{m} 2)$ & $(\mathrm{m} 2)$ & $(\mathrm{m} 2)$ & $(\mathrm{m} 2)$ & $(\mathrm{m} 2)$ & $(\mathrm{m} 2)$ & $(\mathrm{m} 2)$ & $(\mathrm{m} 2)$ \\
\hline$: 400.00$ & $: 400.00$ & $: 400.00$ & $: 400.00$ & $: 400.00$ & $: 400.00$ & $: 400.00$ & $: 400.00$ & $: 400.00$ & $: 400.00$ \\
\hline Altitude & Altitude & Altitude & Altitude & Altitude & Altitude & Altitude & Altitude & Altitude & Altitude \\
\hline$(\mathrm{m})$ & $(\mathrm{m})$ & (m) & (m) & (m) & (m) & (m) & (m) & (m) & (m) \\
\hline$: 690$ & $: 1150$ & $: 1090$ & $: 1050$ & $: 1300$ & $: 1000$ & $: 1050$ & : 750 & $: 650$ & : 900 \\
\hline Aspect & Aspect & Aspect & Aspect & Aspect & Aspect & Aspect & Aspect & Aspect & Aspect \\
\hline (degrees & (degrees & (degrees & (degrees & (degrees & (degrees & (degrees & (degrees & (degrees & (degrees \\
\hline ) & ) & ) & ) & ) & ) & ) & ) & ) & ) \\
\hline$: S$ & $: \mathrm{N}$ & : W & $: S$ & :W & : NW & $: \mathrm{N}$ & : SW & $: S$ & $: \mathrm{N}$ \\
\hline Slope & Slope & Slope & Slope & Slope & Slope & Slope & Slope & Slope & Slope \\
\hline (degrees & (degrees & (degrees & (degrees & (degrees & (degrees & (degrees & (degrees & (degrees & (degrees \\
\hline ) & ) & ) & ) & ) & ) & ) & ) & ) & ) \\
\hline$: 30$ & $: 38$ & $: 30$ & $: 36$ & $: 10$ & $: 31$ & $: 32$ & $: 15$ & $: 31$ & $: 31$ \\
\hline Cover & Cover & Cover & Cover & Cover & Cover & Cover & Cover & Cover & Cover \\
\hline total $(\%)$ & total $(\%)$ & total $(\%)$ & total $(\%)$ & total $(\%)$ & total $(\%)$ & total $(\%)$ & total $(\%)$ & total $(\%)$ & total $(\%)$ \\
\hline$: 90$ & $: 100$ & $: 100$ & $: 85$ & $: 100$ & $: 100$ & $: 100$ & $: 80$ & $: 100$ & $: 100$ \\
\hline Cover & Cover & Cover & Cover & Cover & Cover & Cover & Cover & Cover & Cover \\
\hline tree & tree & tree & tree & tree & tree & tree & tree & tree & tree \\
\hline layer & layer & layer & layer & layer & layer & layer & layer & layer & layer \\
\hline$(\%)$ & $(\%)$ & $(\%)$ & $(\%)$ & $(\%)$ & $(\%)$ & $(\%)$ & $(\%)$ & $(\%)$ & $(\%)$ \\
\hline$: 80$ & $: 100$ & $: 100$ & $: 80$ & $: 100$ & $: 100$ & $: 100$ & $: 80$ & $: 90$ & $: 100$ \\
\hline Cover & Cover & Cover & Cover & Cover & Cover & Cover & Cover & Cover & Cover \\
\hline shrub & shrub & shrub & shrub & shrub & shrub & shrub & herb & shrub & shrub \\
\hline layer & layer & layer & layer & layer & layer & layer & layer & layer & layer \\
\hline
\end{tabular}




\begin{tabular}{|l|l|l|l|l|l|l|l|l|l|}
\hline$(\%)$ & $(\%)$ & $(\%)$ & $(\%)$ & $(\%)$ & $(\%)$ & $(\%)$ & $(\%)$ & $(\%)$ & $(\%)$ \\
$: 10$ & $: 5$ & $: 5$ & $: 10$ & $: 5$ & $: 10$ & $: 20$ & $: 15$ & $: 5$ & $: 10$ \\
Cover & Cover & Cover & Cover & Cover & Cover & Cover & Geology & Cover & Cover \\
herb & herb & herb & herb & herb & herb & herb & $:$ & herb & herb \\
layer & layer & layer & layer & layer & layer & layer & Limston & layer & layer \\
$(\%)$ & $(\%)$ & $(\%)$ & $(\%)$ & $(\%)$ & $(\%)$ & $(\%)$ & e & $(\%)$ & $(\%)$ \\
$: 60$ & $: 30$ & $: 10$ & $: 70$ & $: 45$ & $: 5$ & $: 30$ & Soil & $: 85$ & $: 5$ \\
Geology & Geology & Geology & Geology & Geology & Geology & Geology & $:$ & Geology & Geology \\
$:$ & $:$ & $:$ & $:$ & $:$ & $:$ & $:$ & Cacomel & $:$ & $:$ \\
Limesto & Limesto & Dolomit & Limesto & Limesto & Limesto & Limesto & anosol & Limesto & Limesto \\
ne & ne & e & ne & ne & ne & ne & Rev & ne & ne \\
Soil & Soil & Soil & Soil & Soil & Soil & Soil & $:$ & Soil & Soil \\
$:$ & $:$ & $:$ & $:$ & $:$ & $:$ & $:$ & Waidisc & $:$ & $:$ \\
Calcome & Calcoca & Rendzin & Calcome & Calcome & Calcoca & Calcome & h & Calcome & Calcome \\
lanosol & mbisol & e & lamosol & lanosol & mbisol & lanosol & Compar & lanosole & lanosol \\
Rev & Rev & Rev & Rev & Rev & Rev & Rev & $: 11$ & Rev & Rev \\
$:$ & $:$ & $:$ & $:$ & $:$ & $:$ & $:$ & Crow_c & $:$ & $:$ Zell \\
Waidisc & Sinacher & Sinacher & Tomasc & Tomasc & Gotsuch & Gotschu & ov & Waidisc & Pfarre \\
h & grupf & gupf & hwald & hwald & en & hen & $: 0.7$ & h & Compar \\
Compar & Compar & Compar & Compar & Compar & Compar & Compar & & Compar & $: 28$ \\
$: 4$ & $: 10$ & $: 9$ & $: 15$ & $: 15$ & $: 6$ & $: 8$ & & $: 11$ & Crow_c \\
Crow_c & Crow_c & Crow_c & Crow_c & Crow_c & Crow_c & Crow_c & & Crow_c & ov \\
ov & ov & ov & ov & ov & ov & ov & & ov & $: 1.0$ \\
$: 0.8$ & $: 0.9$ & $: 0.9$ & $: 0.8$ & $: 1.0$ & $: 1.0$ & $: 0.8$ & & $: 0.8$ & \\
& & & & & & & & \\
\hline
\end{tabular}

\begin{tabular}{|c|c|c|c|c|c|c|c|c|}
\hline$\Rightarrow$ & $\Rightarrow$ & $\Rightarrow$ & $\Rightarrow$ & $\Rightarrow$ & $\Rightarrow$ & $\Rightarrow$ & $\Rightarrow$ & $\Rightarrow$ \\
\hline $\begin{array}{l}\text { Relevé } \\
\text { number: } \\
11\end{array}$ & $\begin{array}{l}\text { Relevé } \\
\text { number: } \\
12\end{array}$ & $\begin{array}{l}\text { Relevé } \\
\text { number: } \\
13\end{array}$ & $\begin{array}{l}\text { Relevé } \\
\text { number: } \\
14\end{array}$ & $\begin{array}{l}\text { Relevé } \\
\text { number: } \\
15\end{array}$ & $\begin{array}{l}\text { Relevé } \\
\text { number: } \\
16\end{array}$ & $\begin{array}{l}\text { Relevé } \\
\text { number: } \\
17\end{array}$ & $\begin{array}{l}\text { Relevé } \\
\text { number: } \\
18\end{array}$ & $\begin{array}{l}\text { Relevé } \\
\text { number: } \\
19\end{array}$ \\
\hline $\begin{array}{l}\text { Country } \\
\text { code } \\
\text { : Austria }\end{array}$ & $\begin{array}{l}\text { Country } \\
\text { code } \\
\text { : Austria }\end{array}$ & $\begin{array}{l}\text { Country } \\
\text { code } \\
\text { : Austria }\end{array}$ & $\begin{array}{l}\text { Country } \\
\text { code } \\
\text { : Austria }\end{array}$ & $\begin{array}{l}\text { Country } \\
\text { code } \\
\text { : Austria }\end{array}$ & $\begin{array}{l}\text { Country } \\
\text { code } \\
\text { : Austria }\end{array}$ & $\begin{array}{l}\text { Country } \\
\text { code } \\
\text { : Austria }\end{array}$ & $\begin{array}{l}\text { Country } \\
\text { code } \\
\text { : Austria }\end{array}$ & $\begin{array}{l}\text { Country } \\
\text { code } \\
\text { : Austria }\end{array}$ \\
\hline $\begin{array}{l}\text { Nr. relevé } \\
\text { in table } \\
: 11\end{array}$ & $\begin{array}{l}\text { Nr. relevé } \\
\text { in table } \\
: 12\end{array}$ & $\begin{array}{l}\text { Nr. relevé } \\
\text { in table } \\
: 13\end{array}$ & $\begin{array}{l}\text { Nr. relevé } \\
\text { in table } \\
: 14\end{array}$ & $\begin{array}{l}\text { Nr. relevé } \\
\text { in table } \\
: 15\end{array}$ & $\begin{array}{l}\text { Nr. relevé } \\
\text { in table } \\
: 16\end{array}$ & $\begin{array}{l}\text { Nr. relevé } \\
\text { in table } \\
: 17\end{array}$ & $\begin{array}{l}\text { Nr. relevé } \\
\text { in table } \\
: 18\end{array}$ & $\begin{array}{l}\text { Nr. relevé } \\
\text { in table } \\
: 19\end{array}$ \\
\hline $\begin{array}{l}\text { Cover } \\
\text { abundanc } \\
\text { e scale } \\
:\end{array}$ & $\begin{array}{l}\text { Cover } \\
\text { abundanc } \\
\text { e scale } \\
:\end{array}$ & $\begin{array}{l}\text { Cover } \\
\text { abundanc } \\
\text { e scale } \\
:\end{array}$ & $\begin{array}{l}\text { Cover } \\
\text { abundanc } \\
\text { e scale } \\
:\end{array}$ & $\begin{array}{l}\text { Cover } \\
\text { abundanc } \\
\text { e scale } \\
:\end{array}$ & $\begin{array}{l}\text { Cover } \\
\text { abundanc } \\
\text { e scale } \\
:\end{array}$ & $\begin{array}{l}\text { Cover } \\
\text { abundanc } \\
\text { e scale } \\
:\end{array}$ & $\begin{array}{l}\text { Cover } \\
\text { abundanc } \\
\text { e scale } \\
:\end{array}$ & $\begin{array}{l}\text { Cover } \\
\text { abundanc } \\
\text { e scale } \\
:\end{array}$ \\
\hline $\begin{array}{l}\text { Braun/Bla } \\
\text { nquet } \\
\text { (old) }\end{array}$ & $\begin{array}{l}\text { Braun/Bla } \\
\text { nquet } \\
\text { (old) }\end{array}$ & $\begin{array}{l}\text { Braun/Bla } \\
\text { nquet } \\
\text { (old) }\end{array}$ & $\begin{array}{l}\text { Braun/Bla } \\
\text { nquet } \\
\text { (old) }\end{array}$ & $\begin{array}{l}\text { Braun/Bla } \\
\text { nquet } \\
\text { (old) }\end{array}$ & $\begin{array}{l}\text { Braun/Bla } \\
\text { nquet } \\
\text { (old) }\end{array}$ & $\begin{array}{l}\text { Braun/Bla } \\
\text { nquet } \\
\text { (old) }\end{array}$ & $\begin{array}{l}\text { Braun/Bla } \\
\text { nquet } \\
\text { (old) }\end{array}$ & $\begin{array}{l}\text { Braun/Bla } \\
\text { nquet } \\
\text { (old) }\end{array}$ \\
\hline $\begin{array}{l}\text { Date } \\
\text { (year/mon } \\
\text { th/day) } \\
:\end{array}$ & $\begin{array}{l}\text { Date } \\
\text { (year/mon } \\
\text { th/day) } \\
:\end{array}$ & $\begin{array}{l}\text { Date } \\
\text { (year/mon } \\
\text { th/day) } \\
:\end{array}$ & $\begin{array}{l}\text { Date } \\
\text { (year/mon } \\
\text { th/day) } \\
:\end{array}$ & $\begin{array}{l}\text { Date } \\
\text { (year/mon } \\
\text { th/day) } \\
:\end{array}$ & $\begin{array}{l}\text { Date } \\
\text { (year/mon } \\
\text { th/day) } \\
:\end{array}$ & $\begin{array}{l}\text { Date } \\
\text { (year/mon } \\
\text { th/day) } \\
:\end{array}$ & $\begin{array}{l}\text { Date } \\
\text { (year/mon } \\
\text { th/day) } \\
:\end{array}$ & $\begin{array}{l}\text { Date } \\
\text { (year/mon } \\
\text { th/day) } \\
:\end{array}$ \\
\hline 201 & $2015 / 07 / 2$ & $2015 / 07 / 2$ & $2015 / 07 / 2$ & $2015 / 07 / 2$ & 201 & 201 & 2015 & $2015 / 07 / 2$ \\
\hline 2 & 3 & 3 & 3 & 3 & 3 & 4 & 4 & 4 \\
\hline
\end{tabular}


Determining the Illyrian origin forest communities of beech forests Karawanke - Carinthian alps (Austria)

\begin{tabular}{|c|c|c|c|c|c|c|c|c|}
\hline $\begin{array}{l}\text { Relevé } \\
\text { area (m2) }\end{array}$ & $\begin{array}{l}\text { Relevé } \\
\text { area (m2) }\end{array}$ & $\begin{array}{l}\text { Relevé } \\
\text { area (m2) }\end{array}$ & $\begin{array}{l}\text { Relevé } \\
\text { area (m2) }\end{array}$ & $\begin{array}{l}\text { Relevé } \\
\text { area (m2) }\end{array}$ & $\begin{array}{l}\text { Relevé } \\
\text { area (m2) }\end{array}$ & $\begin{array}{l}\text { Relevé } \\
\text { area }(\mathrm{m} 2)\end{array}$ & $\begin{array}{l}\text { Relevé } \\
\text { area }(\mathrm{m} 2)\end{array}$ & $\begin{array}{l}\text { Relevé } \\
\text { area }(\mathrm{m} 2)\end{array}$ \\
\hline$: 400.00$ & $: 400.00$ & $: 400.00$ & $: 400.00$ & $: 400.00$ & $: 400.00$ & $: 400.00$ & $: 400.00$ & $: 400.00$ \\
\hline $\begin{array}{l}\text { Altitude } \\
\text { (m) }\end{array}$ & $\begin{array}{l}\text { Altitude } \\
\text { (m) }\end{array}$ & $\begin{array}{l}\text { Altitude } \\
\text { (m) }\end{array}$ & $\begin{array}{l}\text { Altitude } \\
\text { (m) }\end{array}$ & $\begin{array}{l}\text { Altitude } \\
\text { (m) }\end{array}$ & $\begin{array}{l}\text { Altitude } \\
\text { (m) }\end{array}$ & $\begin{array}{l}\text { Altitude } \\
\text { (m) }\end{array}$ & $\begin{array}{l}\text { Altitude } \\
\text { (m) }\end{array}$ & $\begin{array}{l}\text { Altitude } \\
\text { (m) }\end{array}$ \\
\hline$: 1050$ & $: 920$ & $: 1080$ & $: 1300$ & $: 1100$ & $: 1100$ & $: 1100$ & $: 1250$ & $: 1250$ \\
\hline $\begin{array}{l}\text { Aspect } \\
\text { (degrees) }\end{array}$ & $\begin{array}{l}\text { Aspect } \\
\text { (degrees) }\end{array}$ & $\begin{array}{l}\text { Aspect } \\
\text { (degrees) }\end{array}$ & $\begin{array}{l}\text { Aspect } \\
\text { (degrees) }\end{array}$ & $\begin{array}{l}\text { Aspect } \\
\text { (degrees) }\end{array}$ & $\begin{array}{l}\text { Aspect } \\
\text { (degrees) }\end{array}$ & $\begin{array}{l}\text { Aspect } \\
\text { (degrees) }\end{array}$ & $\begin{array}{l}\text { Aspect } \\
\text { (degrees) }\end{array}$ & $\begin{array}{l}\text { Aspect } \\
\text { (degrees) }\end{array}$ \\
\hline$: \mathrm{N}$ & $: \mathrm{S}$ & $: 0$ & : NE & $: 42$ & : E & $: \mathrm{W}$ & :W & $: \mathrm{E}$ \\
\hline $\begin{array}{l}\text { Slope } \\
\text { (degrees) }\end{array}$ & $\begin{array}{l}\text { Slope } \\
\text { (degrees) }\end{array}$ & $\begin{array}{l}\text { Slope } \\
\text { (degrees) }\end{array}$ & $\begin{array}{l}\text { Slope } \\
\text { (degrees) }\end{array}$ & $\begin{array}{l}\text { Slope } \\
\text { (degrees) }\end{array}$ & $\begin{array}{l}\text { Slope } \\
\text { (degrees) }\end{array}$ & $\begin{array}{l}\text { Slope } \\
\text { (degrees) }\end{array}$ & $\begin{array}{l}\text { Slope } \\
\text { (degrees) }\end{array}$ & $\begin{array}{l}\text { Slope } \\
\text { (degrees) }\end{array}$ \\
\hline$: 32$ & $: 40$ & $: 0$ & $: 22$ & $: 40$ & $: 29$ & $: 29$ & $: 28$ & $: 25$ \\
\hline $\begin{array}{l}\text { Cover } \\
\text { total }(\%)\end{array}$ & $\begin{array}{l}\text { Cover } \\
\text { total }(\%)\end{array}$ & $\begin{array}{l}\text { Cover } \\
\text { total (\%) }\end{array}$ & $\begin{array}{l}\text { Cover } \\
\text { total }(\%)\end{array}$ & $\begin{array}{l}\text { Cover } \\
\text { total }(\%)\end{array}$ & $\begin{array}{l}\text { Cover } \\
\text { total (\%) }\end{array}$ & $\begin{array}{l}\text { Cover } \\
\text { total (\%) }\end{array}$ & $\begin{array}{l}\text { Cover } \\
\text { total }(\%)\end{array}$ & $\begin{array}{l}\text { Cover } \\
\text { total }(\%)\end{array}$ \\
\hline$: 100$ & $: 100$ & $: 100$ & $: 100$ & $: 100$ & $: 100$ & $: 100$ & $: 80$ & $: 100$ \\
\hline $\begin{array}{l}\text { Cover } \\
\text { tree layer } \\
(\%)\end{array}$ & $\begin{array}{l}\text { Cover } \\
\text { tree layer } \\
(\%)\end{array}$ & $\begin{array}{l}\text { Cover } \\
\text { tree layer } \\
(\%)\end{array}$ & $\begin{array}{l}\text { Cover } \\
\text { tree layer } \\
(\%)\end{array}$ & $\begin{array}{l}\text { Cover } \\
\text { tree layer } \\
(\%)\end{array}$ & $\begin{array}{l}\text { Cover } \\
\text { tree layer } \\
(\%)\end{array}$ & $\begin{array}{l}\text { Cover } \\
\text { tree layer } \\
(\%)\end{array}$ & $\begin{array}{l}\text { Cover } \\
\text { tree layer } \\
(\%)\end{array}$ & $\begin{array}{l}\text { Cover } \\
\text { tree layer } \\
(\%)\end{array}$ \\
\hline$: 100$ & $: 100$ & $: 70$ & $: 100$ & $: 100$ & $: 100$ & $: 100$ & $: 70$ & $: 80$ \\
\hline Cover & Cover & Cover & Cover & Cover & Cover & Cover & Cover & Cover \\
\hline shrub & shrub & shrub & shrub & herb layer & herb layer & herb layer & herb layer & shrub \\
\hline layer (\%) & layer (\%) & layer $(\%)$ & layer $(\%)$ & $(\%)$ & $(\%)$ & $(\%)$ & $(\%)$ & layer $(\%)$ \\
\hline$: 10$ & $: 10$ & $: 5$ & $: 2$ & $: 80$ & $: 5$ & $: 5$ & $: 20$ & $: 40$ \\
\hline Cover & Cover & Cover & Cover & Geology & Geology & Geology & Geology & Cover \\
\hline herb layer & herb layer & herb layer & herb layer & & & : & & herb layer \\
\hline$(\%)$ & $(\%)$ & $(\%)$ & $(\%)$ & Dolomite & Limeston & Limstone & Limstone & $(\%)$ \\
\hline$: 5$ & $: 20$ & $: 50$ & $: 10$ & Soil & e & coluvium & coluvium & $: 60$ \\
\hline Geology & Geology & Geology & Geology & & coluvium & Soil & Soil & Geology \\
\hline : & : & : & : & Rendzine & Soil & : & : & : \\
\hline Dolomite & Dolomite & Limeston & Limstone & Rev & : & Rendzine & Rendzine & Limstone \\
\hline Soil & Soil & e & coluvium & & Rendzine & Rev & Rev & Soil \\
\hline : & : & Soil & Soil & Baerental & Rev & : & : & : \\
\hline Rendzine & Rendzine & : & : & Compar & & Zellwnkel & Zellwinke & Calcomel \\
\hline Rev & Rev & Calcomel & Rendzine & $: 4$ & Baerental & Compar & & anosol \\
\hline : Zell & : Widisch & anosol & Rev & Crow_co & Compar & $: 4$ & Compar & Rev \\
\hline Pfare & Compar & Rev & : & V & $: 5$ & Crow_co & $: 3$ & : \\
\hline Compar & $: 2$ & : Beaental & Baerental & $: 0.9$ & Crow_co & v & Crow_co & Zellwinke \\
\hline$: 29$ & Crow_co & Compar & Compar & & v & $: 1.0$ & $\mathrm{v}$ & 1 \\
\hline Crow_co & $\mathrm{v}$ & $: 17$ & $: 18$ & & $: 1.0$ & & $: 0.7$ & Compar \\
\hline $\mathrm{v}$ & $: 0.9$ & Crow_co & Crow_co & & & & & $: 5$ \\
\hline$: 1.0$ & & $\begin{array}{l}\mathrm{v} \\
: 7.0\end{array}$ & $\begin{array}{l}\mathrm{V} \\
: 0.9\end{array}$ & & & & & $\begin{array}{l}\text { Crow_co } \\
\mathrm{V} \\
: 0.8\end{array}$ \\
\hline
\end{tabular}

